\title{
What Happens When You Tell Somebody Else's Story?
}

\author{
ALEXIS WRIGHT
}

\begin{abstract}
Who writes about Aboriginal people, and what effect that has upon Aboriginal people and the national narrative about Aboriginal people are explored in this paper, which is comprised of key excerpts from an award-winning longer essay I have written. While we are all collectively the inheritors and generators of the country's psyche and national narrative, the absence of recognition has effectively silenced Aboriginal people from contributing their own story to this narrative.
\end{abstract}

Key words: Australia, Aboriginal, psyche, culture, storytellers, control, recognition,

Through many years of researching stories from all over the world and through my own

This is the author manuscript accepted for publication and has undergone full peer review but has not been through the copyediting, typesetting, pagination and proofreading process, which may lead to differences between this version and the Version of Record. Please cite this article as doi: $10.1002 /$ aps.1576

This article is protected by copyright. All rights reserved. 
communities, which I have always felt I had to do to understand how to be useful in my work - including being a writer - I have grown more curious about what would impact on my ability to tell stories that might be embraced anywhere in the world.

It has been a life's work of growing increasingly aware of how other people were telling stories on behalf of Aboriginal people in Australia, and how stories are used in campaigns to achieve certain goals. I think it would be fair to say that we are the country's troubling conscience and managed by its most powerful power brokers through a national narrative. I saw the fallout of this changing negative narrative in our communities, and in the lifetime of hard work our people do to fight against each political story-making trend.

I knew the style and intent of the national narrative would always be one of the greatest challenges I would have as a writer. We are all collectively the inheritors and generators of the country's psyche, and I wanted to know how I would be affected by this. The way that this country shapes its people would constantly be on my mind while trying to tell stories of who we are, how we see the world, what our traditional ground means to us, and our desires and ambitions. The cloud is always present. 
Aboriginal people have not been in charge of the stories other people tell about us. The question then was, how should I be an Aboriginal writer when the stories that were being told nationally about us would shape and impact on what I can do as a writer? I wanted to explore what happened in our imagination and our creative efforts when we write under the cloud of those who fear us, and who instill their fear in us. Why do I write at all? And why do I write what I write? These are questions I wanted to explore while trying to create stories more authentically; and I wondered, am I just telling stories I have been conditioned to tell by the stories other people tell about us? How would I free my mind to write differently?

When it comes to how our stories are being told, supposedly on our behalf, or for our interest or supposed good, it has never been a level playing field. We do not get much of a chance to say what is right or wrong about the stories told on our behalf - which stories are told or how they are told. It just happens, and we try to deal with the fallout. I think we often feel it is pointless to take on the endless stream of other people's points of view about us that comes through the media, or to make the effort any more to turn around each new and mostly negative storytelling trend. The truth is, we have simply 
become other people's subject matter in the stories they tell, and pay the high price of their foolishly playing around with the Aboriginal sense of self, aimed at dismantling our knowledge and belief in our rights, to have us question our truths and our times.

Foolishness is another word for stupidity, and this is generally what the national narrative about Aboriginal people has been, because its bottom line has never changed. The plot line has always been for one outcome, to erode Aboriginal belief in sovereignty, self-governance and land rights, even when it has gotten to the point where most Aboriginal people have been silenced, or feel too overwhelmed to fight any more. Look at the years where it was impossible to mention the words treaty, sovereignty or even land rights without creating a major backlash in the media. The term "native title" was non-existent in the national lexicon of Australia until the 1990s, when Eddie Mabo overturned the commonly accepted term of terra nullius - empty country on White settlement.

I have seen firsthand the shameful and injurious impact that many public stories have had on of our people over a long period of time. We have been boxed in by the Australian psyche, its fear of the other. It is widely understood that we are being 
pressured by this country to assimilate, to abandon our culture in order to survive. This was confirmed in a recent study undertaken of hundreds of Aboriginal people in Darwin by the Larrakia Nation in the Top End, together with the University of Sydney and the University of Tasmania. A former head researcher of the Larrakia Nation, Penny Taylor, noted that Aboriginal people hear a lot about themselves from the non-Indigenous population: "They run the newspapers, they're on air, there are the politicians that are speaking out, but we don't hear much from the Indigenous population themselves" (cited in Lawford, 2016).

Many of our people continue to be treated like third-class citizens in every aspect of their daily interactions with white people, from the bus drivers who keep driving because they see blackfellas at the bus stop, to harassment by police and being over jailed in an overpoliced Northern Territory, or the brutal treatment of our children as we saw at Don Dale Youth Detention Center in Darwin. We are not able to choose a future of cultural independence while the burden on Aboriginal lives grows greater due to the continued denial of hundreds of millions of dollars on a yearly basis, over decades, by the governance arrangements of the Northern Territory. Take your pick. All the statistics are 
linked to the national narrative, to story-making, to the way that stories are told, to keep the status quo in place.

This means that we work to other people's direction whether we want to or not, to what the government has prescribed for us to do to keep us busy and distracted. We are in a cesspit, and far from concentrating on any meaning drawn from a fuller Aboriginaldefined sense of self, where we may have learnt more from the legacy of ancestral law stories that had been passed down through the ages from our own people for the purpose of keeping this country alive. We need these laws for understanding others, to realize ourselves fully and to give ourselves a greater capacity in understanding how to live on our own culturally attuned economic, social and sustainable terms. Instead, we have just about been overcome, smothered by and immersed in the control of outside narratives. It is almost a miracle wherever you find a really solid Aboriginal-defined vision forging its way through a maze that only seems to work to destroy possibility.

In about 40 years of working for Aboriginal rights I have never really seen a fully Aboriginal-defined and -endorsed vision being given serious attention in the Australian media. What I mean by an Aboriginal-defined vision is one I saw formed by the elders in 
central Australia across some of the very best of their communities during the 1990s, where they called for Aboriginal self-government in the Northern Territory. There has never been a real discussion in Australia about how to create Aboriginal self-government in the Northern Territory.

The story of the call by elders of central Australia for Aboriginal selfgovernment, for instance, was killed before it could breathe. It was like so many other good stories from Aboriginal people that have either become compromised, gone underground to survive or are only shared in private and safe environments. Yet why is it that there has never been the will in the country as a whole to listen to an Aboriginaldefined vision?

Once upon a time I believed that we had the right to tell our stories and articulate our vision for developing the health of our people, culture, land and economic power. I believed that our survival depended on strengthening the cornerstones of our humanity through our ideas of self-governance in the modern age, even with a reliance on government to overcome the long-term damage caused by dysfunctional and unworkable government policies. In reaching this vision I always thought it was about having hope, 
where our stories were the most valuable tool of the heart and mind for maintaining hope in the struggles that were taking place.

The publication of story after story blaming the victim for failing to demonstrate any responsibility for their struggling and poverty-stricken communities has had the intended effect. Even some of our people started to believe they could not handle selfdetermination, that they were violent and lazy, welfare dependent, did not care for their children and needed to be controlled. From the beginning of that highly orchestrated conservative theater, the story war has run on. It is in the blood. Everyone has caught the disease in some measure. It is now accumulated history, just as what was learnt through the history wars, which were basically a pitiful argument pushed by conservative academics who felt disenfranchised and unheard, to question whether the killings of Aboriginal people during the early colonial settlement were acts of genocide, and whether such killings actually happened.

The roll-on effect of a politically hyper-charged race-based strategy for controlling Aboriginal stories is to keep Aboriginal self-censorship in place, and at no real cost to the government. It is a cheap strategy. But the cost of what has happened to 
us is enormous. Think of the cost of removing Aboriginal self-censorship, and the cost of allowing Aboriginal people to have real storytelling rights and justice platforms to work towards their vision of the future. The cost will continue to escalate, and the cost at this point in time, would possibly be more than the country could afford. It would mean the end of a history of wasteful government policies that have never worked, or were not meant to do any work other than to ensure votes at election time, and so keeping everything contained at a minimum cost, to ensure that real money will never be spent overcoming the injury of colonization.

The only solution that Australian governments have really come up with is for the complete assimilation of Aboriginal people, even as the cost of this failure increases but it may not even be the goal, when it is always easy to accuse Aboriginal people of failure for political expediency, and of being victims if they do not hit the road to assimilation. So there is a general assumption that Aboriginal people are victims and only tell victim stories. This results in further loss in our ability to create some of the best stories of this country, as we lean in to do what is expected of us. In the injurious nature of the realities for Aboriginal people, the full cost will be borne in the stories we can tell to shape our 
world. Our heritage will always be weighed by how prepared we are to compromise or lose sight of our cultural storytelling vision. The further we bend our stories to suit mainstream Australia, resulting in further loss of our cultural norms, the more we hasten our total acculturation into mainstream Australian society. Why? Because we will lose what is special about our inheritance if we cannot understand it or fight for it. One might ask, why can't we have it both ways? This is the tricky question about Aboriginal storytelling.

Stories from Aboriginal people about rights will be ineffective if these stories fall on deaf ears - even our own. Our stories may never be heard or taken seriously by those who pay lip service to Aboriginal rights. These stories mean nothing to them and will be unappreciated and not run in the mainstream media, or will be rendered unfathomable. Who would know how to read stories encompassing all time, when most are incapable of understanding the stories of the earth and the long cultural heritage of this country?

With no dedicated platform for developing stories about Aboriginal rights, including cultural and economic sovereignty and security, as time goes by there will be even fewer options for Aboriginal people to tell their stories without compromising or 
further eroding fundamental principles of culture and belief. Aboriginal storytellers may feel the need to make more deliberate choices in the way we tell stories, as many did from the force of criticism during the early Intervention years. We might ask, how will my story be heard? What is the new benchmark of articulation here? We risk our cultural existence, authenticity and voice if we accept a pattern of compromise by trying to construct a story or belief that matches the mainstream national story for Aboriginal people.

A number of us might just allow other people to continue looking after our communities as the storytellers in the current pattern of closing the gap, because we have lost confidence in our ability to articulate our own stories. Some of us may have taken the decision to live in a more specialized form of interior separatism, where we only recognize and remain familiar with the value of continuing cultural laws, ideas and beliefs, where our lives seem to make sense, have security and surety, while the surface appears both part colonized and controlled. We will continue, despite government policies, practicing a rich Aboriginal culture in virtual isolation, and in relative peace, even though the struggle to maintain culture without resources, or being dependent on 
outside resources, will always be there, and one of the biggest issues of our survival. But vision is not beyond us, in spite of the national narrative that belittles us.

The repetitive closing the gap narrative and platform has become even more firmly established in the mind of Australians, and works to deepen Aboriginal selfconsciousness and self-censorship. Australians have been trained to think in this new way, and now expect Aboriginal people to reset their behavior to approximate the official story. How we choose our own reference points, and how we develop these practices, will be one of the most important stories of our times.

\section{REFERENCES}

$<$ EPATH >Lawford, E. (2016). Aboriginal people feel pressured to lose values, culture to be successful, study says. ABC News.

Wright, A. (2017). What happens when you tell somebody else's story? Meanjin, 75(4), $58-76$. 
Alexis Wright

alextol@bigpond.com

This article is protected by copyright. All rights reserved. 


\section{ARTICLE FRONT SHEET}

$<A R T T Y$ ARTTY="BR".>

(Select from $R A, R V, R L, S C, E D, B R, E R, C R, X X$ )

$<$ CATEG $>$ Research Article</CATEG $>$

<TOCCATEG >Research Articles</TOCCATEG>

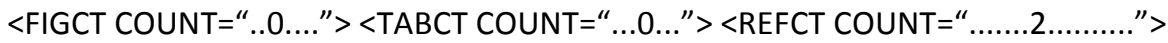

$<$ CRNG PUBL="YES" $><$ CRLN>Copyright \&copy; 2018 John Wiley \&amp; Sons, Ltd. $</ C R L N>$

$<$ CRNM > John Wiley \&amp; Sons, Ltd. $<$ CRNM $><$ CRYR YEAR="2018" $><$ CRYR $></$ CRNG $>$

\section{First page headline}

International Journal of Applied Psychoanalytic Studies

Int. J. Appl. Psychoanal. Studies 15 (0): 000-000 (2018)

Published online in Wiley Online Library

(wileyonlinelibrary.com) DOI: 10.1002/aps.1576

\section{Article title $<\mathrm{ATL}>$}

What Happens When You Tell Somebody Else's Story?

Verso $<$ SHORTTL $>$

Wright

Running footlines (recto and verso)

Copyright (C) 2018 John Wiley \& Sons, Ltd.

Int. J. Appl. Psychoanal. Studies 12: 000-000 (2018)

DOI:10.1002/aps

If there are other SGML tags required for this article, such as Special editor $\angle$ SPEDG > (at ms level) (SPED, FNMS, $S N M, A F F S)$; Conference group <CNG > (CNDF, CNDL, CNM, CNN, CNP, CNS); or Contract/grant info <CG> (CGS, CGN) then please write the details beneath here (and continue overleaf).

\section{PROOFING INSTRUCTIONS}

\begin{tabular}{|c|c|c|}
\hline Author E-mail & \multicolumn{2}{|l|}{ alextol@bigpond.com } \\
\hline Editor & \multicolumn{2}{|l|}{ Nadia Ramzy } \\
\hline Editor E-mail & ramzyland@msn.com & \\
\hline Copyr & ransfer Agreement (CTA) & Please send CTA form to author. \\
\hline
\end{tabular}

This article is protected by copyright. All rights reserved. 


\section{University Library}

\section{- M M N E R VA A gateway to Melbourne's research publications}

Minerva Access is the Institutional Repository of The University of Melbourne

Author/s:

Wright, A

Title:

What Happens When You Tell Somebody Else's Story?

Date:

2018-06-01

Citation:

Wright, A. (2018). What Happens When You Tell Somebody Else's Story? International Journal of Applied Psychoanalytic Studies, 15 (2), pp.136-139. https://doi.org/10.1002/ aps.1576.

Persistent Link:

http://hdl.handle.net/11343/284966 